\title{
Assessing Listening using 21st Century Skill Perspective in Higher Education
}

\author{
Sukma Nur Ardini ${ }^{1}$, Dwi Rukmini ${ }^{2}$, Warsono ${ }^{3}$, Dwi Anggani Linggar Bharati ${ }^{4}$ \\ \{sukmanurardini@upgris.ac.id ${ }^{1}$, wiwidwirukmini@yahoo.com², warsonopps@yahoo.co.id ${ }^{3}$, \\ dwi_anggani@yahoo.com\} \\ Universitas PGRI Semarang, Jl. Gajah Raya No. 30, Semarang, Indonesia ${ }^{1}$, Universitas Negeri \\ Semarang, Jl. Kelud Utara III, Semarang, Indonesia ${ }^{234}$
}

\begin{abstract}
Assessment is crucial part in learning and should employ 21st century skills. The present study aimed at investigating the assessment of the redesigned listening test as well as describing the process and result achieved by the students in detail. It was a case study research design with 91 students of second semester taken using purposive sampling at Universitas PGRI Semarang. The data collected through documents review, test, in-depth interview, then, descriptively analyzed. The findings showed that top-down was way more difficult than bottom-up since the lowest average score was part D (9\%), part C $(26 \%)$, part B $(30 \%)$ and part A $(35 \%)$. It evidenced the test can be wellimplemented. The interview result said it created more excitement for the students. It might have implication to the development of alternative instrument to create more creative and innovative assessment items to proof that teaching listening can be interesting as well as challenging.
\end{abstract}

Keywords: Assessment, listening, 21st century skill, higher education

\section{Introduction}

In Indonesia, the importance of the 21 st century skills over higher education level has been regulated in the Ministry of Research, Technology, and Higher Education No 44 Year 2015 about Indonesian National Qualification Framework or Kerangka Kualifikasi Nasional Indonesia (hereafter $K K N I$ ). $K K N I$ is a framework of working qualification classes which juxtaposes, equalizes, integrates, education sector and training and working experience in order to grant working recognition of competences in accordance to the position of employment in different sectorsn (2015, Article 1, Paragraph 5). Based on the policy, higher education curriculum should employ what is meant by the 21 st century skills which refer to collaboration, digital literacy, critical thinking, and problem solving skill. Hence, the cognitive domain used in higher education also needs to be improved. It is no more in the level of remembering $(\mathrm{C}-1)$, understanding $(\mathrm{C}-2)$, and applying $(\mathrm{C}-3)$ but it must be higher that is on the level of analyzing (C-4), evaluating (C-5), and creating (C-6). Therefore, each course implemented in higher education curriculum must be integrated with those requirements as well as the assessment.

Assessment is crucial part in learning. It can be the tool not only to measure quality of learning that educators have given to students but also to measure how far the cognitive process receives the learning. As William said that assessment is the bridge between teaching 
and learning [1]. Then, an assessment must be able to test the whole competencies that must be had by the students.

Listening is the most basic language skill among other skills. Human being must listen first before they speak, read or even write. Considering the importance of listening skill, it should have gotten much attention. The present study was started by the observation result conducted by the researchers. In Universitas PGRI Semarang, listening got less attention compared to the other skills since the output of the receptive skills (listening and reading) is invisible. Different from productive skills (speaking and writing), the competence of the students is visible so it can be easily measured. It becomes the reason why listening course seems neglected and underrated (Richards\&Renandya; Walker; Ardini, S.N) [2,3,4]. Therefore, the study used the redesigned listening test that was formulated based on two cognitive viewpoints; 1) the cognitive domain used in KKNI based on Bloom's Taxonomy of Learning (Krathwohl; Brown; Richards) [5,6,7], 2) the cognitive process of listneing skill (Vandergrift\&Goh) [8]. The result of the redesigned listening test was presented in the 7 th International Conference on New Trends in English Language Teaching and Testing, 17 March 2019 in Dubai, UAE [9].

Thus, the objectives of the study was to investigate the implementation of the redesigned listening test using 21 st century skill perspective. This area of research is important in order to provide detail analysis about the implementation of a well-designed listening assessment as required by $K K N I$ curriculum as well as to give evidence that listening can be interesting and challenging course.

\section{Method}

It was a case study research design since the researchers tried to describe the phenomena using Creswell [10] which the goal is to arrive at a detailed description and understanding of the entity or the case. The site of the study was in Universitas PGRI Semarang, Central Java, Indonesia, with the population of 140 students of second semester of English Education Department in the academic year 2018/2019. The sampel of the study was 91 students taken using purposive sampling technique.

The data were collected through documents review, test, and in-depth interview. The documents review dealt with some documents such as syllabus, lesson plan, and the redesigned listening test along with the audios/videos. Then, the students were tested using the redesigned test before they got interviewed by the researchers in order to collect deeper data using open-ended question type. This step involved both lecturer and students in order to reveal their perception.

The data were then analyzed descriptively. Numbers existed in the study was used to measure the listening assessment in detailed descriptions.

\section{Result and Discussion}

It was mentioned earlier that the objectives of the study was to investigate the implementation of the redesigned listening test, the findings described the process of the assessment as well as the result achieved by the students on each part, as follows: 


\subsection{Part A}

Part A comprised the cognitive of analyzing, intensive and bottom up processing. The result of listening test part A was shown by the figure 1 . Figure 1 revealed that $85.3 \%$ of the students were able to answer correctly while $14.7 \%$ students were not. It means most of the students did not find any problems in this type of question. By the total number of 5 items of questions, it was found that the correct answer of each item is $90,90,63,75$, and 70 . The data showed that students got more difficulties for questions number 3 (63) and 5 (70).

The result of the interview showed that the problems were among sounds $/ \mathrm{t} /$ and suffix past tense /d/ in words "shout up" and "showed up" as well as sounds /eir/ in words "their right" and "they're right". Those are because of their lack of understanding about phonology and morphology, mostly were the most similar phonemes and morphemes. In this case, the $14.7 \%$ of the incorrect students did not realize only on past tense allomorph /d/ but also in lexical meaning of word "right". When they understood word "right" in this context is a noun instead of an adjective, they will not pick the incorrect answer.
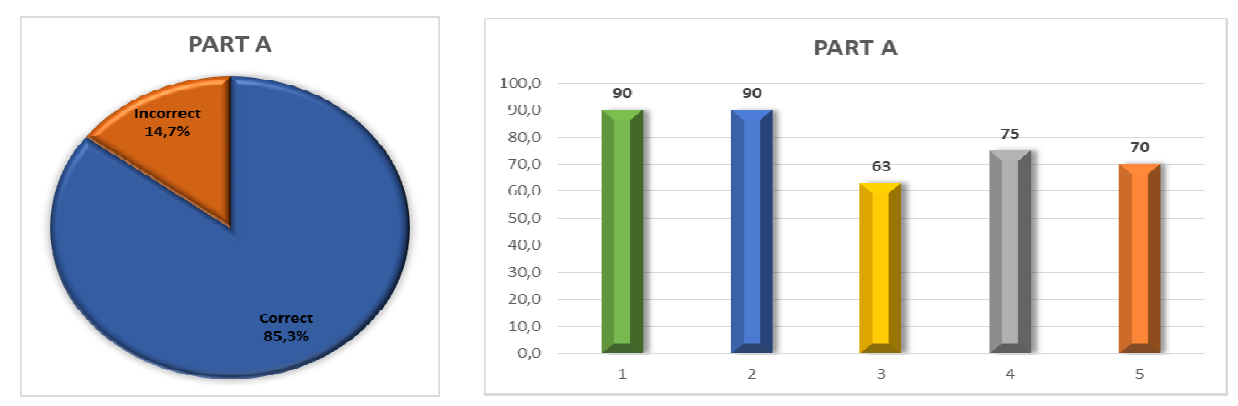

Fig. 1. The Students` Result of Part A

\subsection{Part B}

Part B employed analyzing, selective, and bottom up processing. Even though part A and $B$ had the same level of cognition domain, but they were different in task. The result of listening test part B was shown by the figure 2. It revealed that $71.4 \%$ of the students were able to answer correctly while $28.6 \%$ students were not. It means most of the students also did not find any problems in this type of question. By the total number of 5 items of questions, it was found that the correct answer of each item is $52,70,71,80$, and 52 . The data showed that students got more difficulties for questions number 1 and 5 with the total correct answer of 52 .

The result of the interview showed that the problems were among the detail description about the floor plans and the dress. Since they cannot understand the clues given by the speaker, they will not be able to pick the correct answer. In this case, the $28.6 \%$ of the incorrect students missed the information about which room they like and avoid. While the interview result on question 5 proofed that they were lacking in understanding some vocabularies such as pattern, courage, suit, reserved, flashy, etc. 

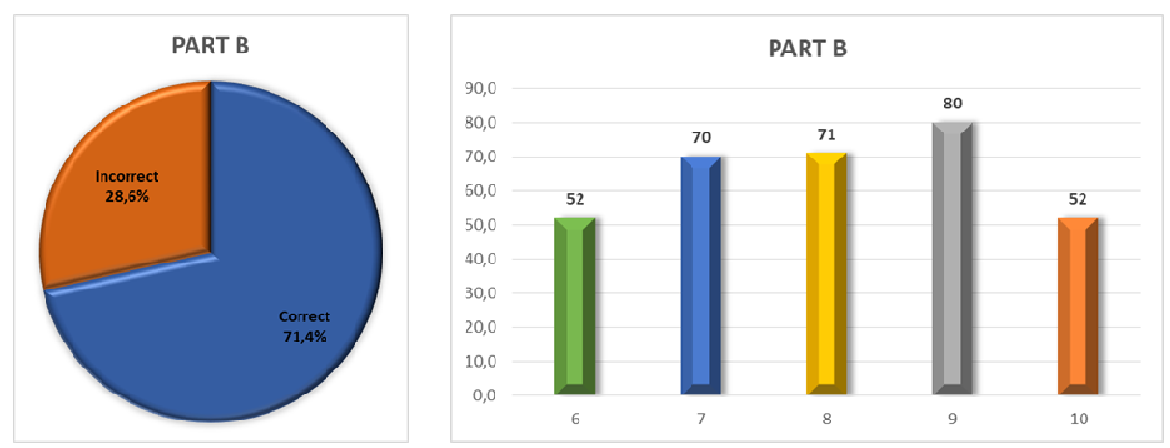

Fig. 2. The Students' Result of Part B

\subsection{Part C}

Part $\mathrm{C}$ included evaluating, responsive, and top down processing. The result of listening test part $\mathrm{C}$ was shown by the figure 3 . It revealed that $78.8 \%$ of the students were able to answer correctly while $21.2 \%$ students were not. It means this type of question was not too difficult for the students. By the total number of 4 items of questions, it was found that the correct answer of each item is 69,67,74, and 77. The data showed that students got more difficulties for questions number 2 and 1 with the total correct answer of 69 and 67. Comparing to the preceding parts, this part was assumed more problematic since the highest correct answer was only 77, while the preceding parts reached more than that.

The result of the interview showed that the problems were the detail information about the topic, such as who, where, why, when and how. This part also do not remain a bottom-up but a top-down processing where the students need to understand the meaning of the spoken topic in order to get the message then they are able to answer the questions followed, otherwise they missed all of the information and had no idea in the process of answering questions.
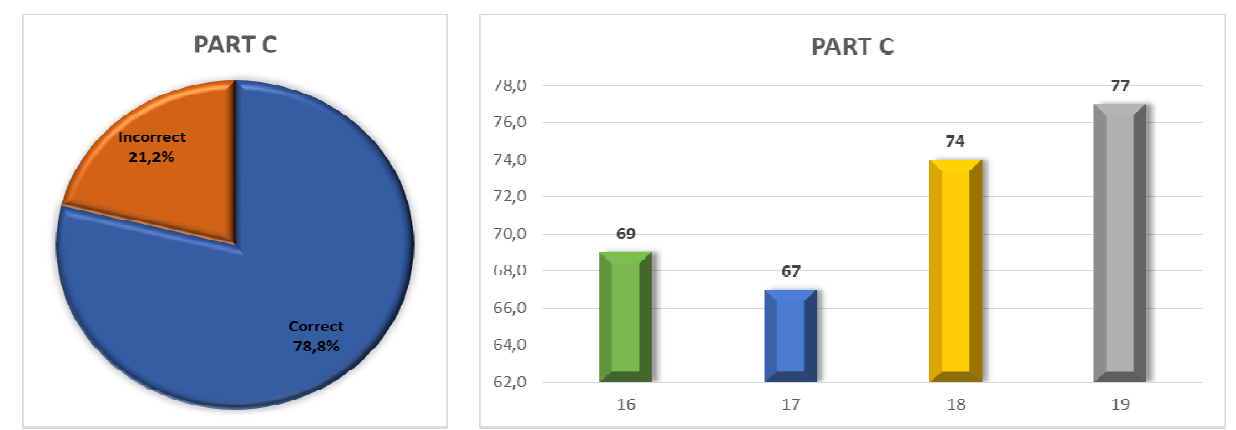

Fig. 3. The Students' Result of Part C

\subsection{Part D}

The last part of the redesigned listening test was part D. It employed creating, extensive and top down processing. Since creating is the highest level of cognitive domain, this part produced spoken output of student in formulating one's situation. The result of listening test part $\mathrm{D}$ was shown by the figure 4 . It revealed that $26.0 \%$ of the students were able to answer 
correctly while $74.0 \%$ students were not. It means this type of question was categorized way too difficult for the students since most of them were not able to answer the question well. By the total number of 2 items of questions with 3 points of each item, it was found that the correct answer of item 1 is 25, 30 and 16, while item 2 is 33, 24 and 14. The scoring system for part D included vocabulary, grammar and content. The data showed that all of the items were low but the lowest correct answer were at item 3 (16) and 6 (14) which those are the answers about content. Comparing to the preceding parts, this part was assumed the most problematic since the highest correct answer was only 33, while the preceding parts reached way more than that.

The result of the interview showed that the problems were they did not understand the gist, main idea also purpose of the recording which led them into confusion and loss of ideas. Some said that it needed to replay more and more since they did not get any important clues to answer those questions.
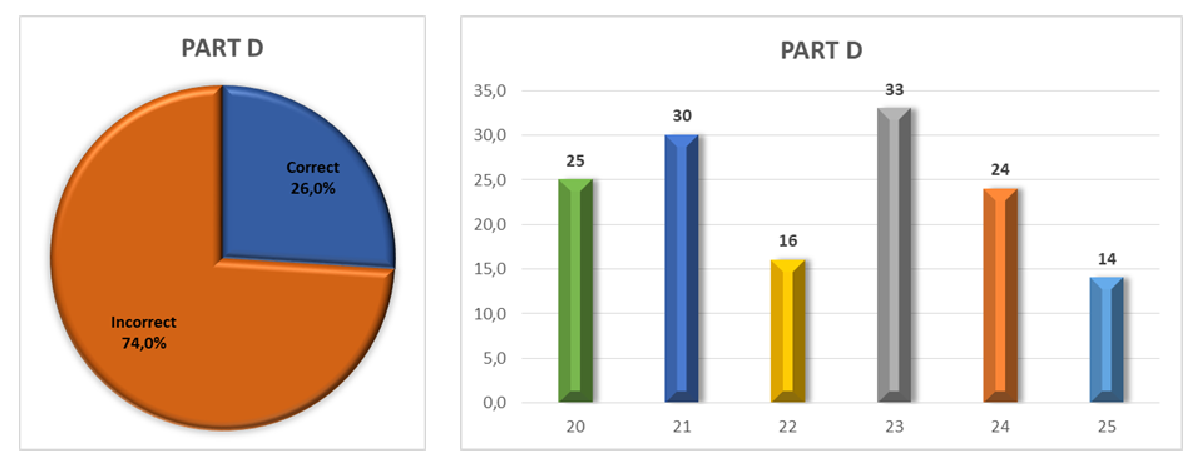

Fig. 4. The Students' Result of Part D

\subsection{The Average Scores}

By conducting the test, it was revealed that the average score of those parts shown by the figure 5. From the figure above, the average score from part A to D was resulted gradually from the highest to the lowest. The highest was part A with $35 \%$ of percentage, followed by part B which got the percentage of $30 \%$, part C that was $26 \%$ and the lowest was part D which got the percentage of only $9 \%$. The data yielded were in line with the interview result that they problems were about; phonology and morphology also lexical matters; detail vocabularies such as pattern, courage, suit, reserved, flashy and so on; detail information about the topic, such as who, where, why, when and how; and the last was about understanding the gist, main idea also purpose of the recording which led them into confusion and loss of ideas.

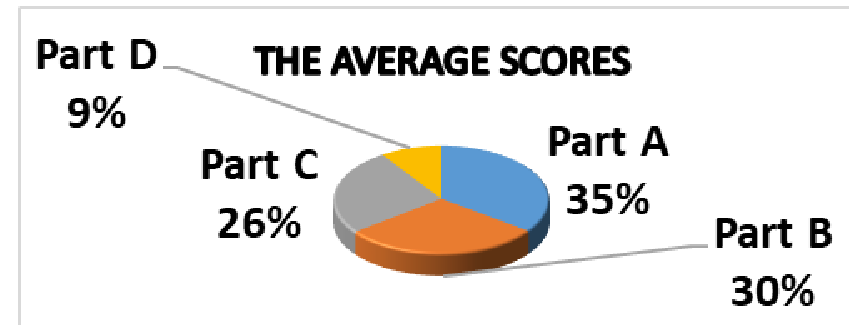

Fig. 5. The average score of each part of questions 


\subsection{The Result of Students' Scores}

The last finding of the study was the students' scores as the assessment implementation achievement of the redesigned listening test, shown by the figure 6 . After the redesigned listening test done, then the scores of the students were calculated. The result showed that $14.3 \%$ or 13 students were categorized excellent, $25.3 \%$ or 23 students were categorized good, $44.0 \%$ or 40 students were categorized adequate, $9.9 \%$ or 9 students were categorized less adequate, and $6.6 \%$ or 6 students were categorized failed. The interview result toward the sample subject was positive. They said that the test was way more interesting and challenging than the listening test they have ever done before. Therefore, it can be assumed that the redesigned listening test was successfully conducted through the second semester of Universitas PGRI Semarang.

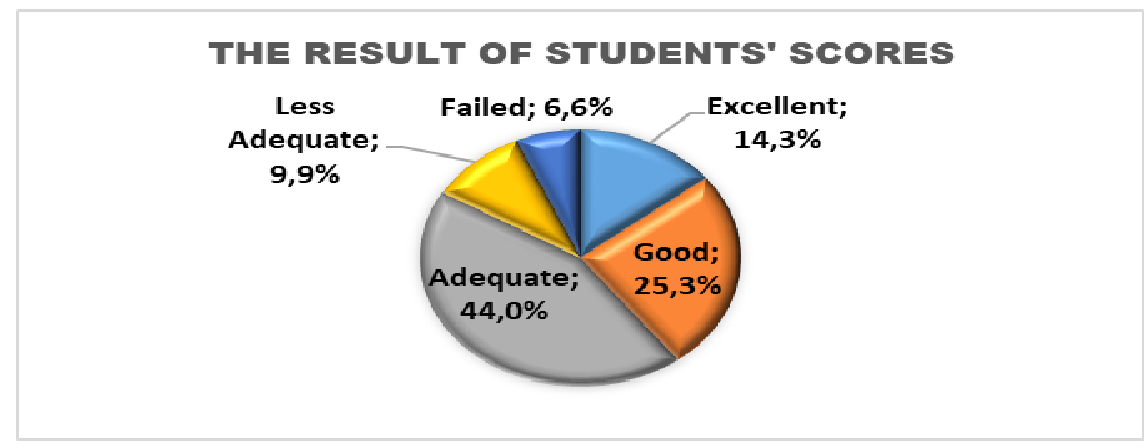

Fig. 6. The Result of Students' Scores

\section{Conclusions}

To sum up, this study was aimed at investigating the assessment of the redesigned listening test in higher education. The findings as well as the interview showed that the students got difficulty when they were facing questions related to top-down processing rather than bottom-up processing, e.g. part D of the redesigned listening test. Overall, the final scores achieved by the students proofed that the redesigned listening test can be implemented, it created more excitement for the students instead. These findings might have implication to the development of alternative instrument to create more creative and innovative assessment items to proof that teaching listening can be interesting as well as challenging. 


\section{References}

[1] William, Dylan.: Assessment: The Bridge between Teaching and Learning. Voices from the Middle, Volume 21 Number 2, December (2013)

[2] Richard, Jack C and Renandya, Willy A.: Methodology in Language Teaching. Cambridge: Cambridge University Press (2010)

[3] Walker, N.: Listening: the most difficult skill to teach. Encuentro 23, 2014, pp.167-175 (2014)

[4] Ardini, S.N.: Top-Down and Bottom-Up Processing in Listening. Which one is Problematic?: A Case of Universitas PGRI Semarang. English Teaching Journal. Volume 6 Number 2, August (2015)

[5] Krathwohl, D. R.: A revision of Bloom's Taxonomy: an overview. Theory into Practice, Volume 41, Number 4, College of Education, The Ohio State University (2002)

[6] Brown, H. Douglas.: Language Assessment Principles and Classroom Practices. California: Longman University Press (2004)

[7] Richards, Jack C.: Teaching Listening and Speaking: From Theory to Practice. USA: Cambridge University Press (2008)

[8] Vandergrift, L., Goh, C.: Teaching and Learning Second Language Listening. New York: Taylor \& Francis (2012)

[9] Ardini, S.N. et. al.: Redesigning the 21st Century Listening Test to Stimulate Students'Critical Thinking using Project, Problem, and Discovery Learning: an Effort to Arise the Underrated Skill. Conference Proceedings of 7th International Coference on New Trends in English Language Teaching and Testing. Dubai, UAE. March 17 (2019)

[10] Creswell, J. W.: Educational research: Planning, conducting and evaluating quantitative and qualitative research (4th ed.). Boston: Pearson Education Inc (2012) 